Dr. Gönül Yazgan-Sağ

Gazi University

Ankara, Turkey
Original scientific paper

UDC: 371.95

DOI: $10.5937 /$ IstrPed2002121Y

\title{
POSSIBLE INTERACTIONS WITH MATHEMATICALLY GIFTED STUDENTS: VIEWS OF PROSPECTIVE TEACHERS ${ }^{2}$
}

\begin{abstract}
Teachers' interactions with mathematically gifted students in the classroom environment, and the elements of this interaction have become prominent recently. This qualitative study's purpose is to reveal the views of prospective secondary mathematics teachers about these interactions. The study participants were seven prospective teachers attending the fourth year of a secondary mathematics teaching programme in a public university in Turkey during the 2018-2019 academic year. These prospective teachers participated in a 90-minute focus group interview which was recorded with a video camera. During the interview, the researcher brought up possible classroom environment scenarios that could occur with mathematically gifted students who may have the characteristics that the participants described. The prospective teachers' views about the kinds of behaviours they can exhibit, and what methods they can reveal in these theoretical interactions were analysed with the descriptive analysis method. The study results indicated that the participants exhibited different approaches to situations they might encounter in the classroom. For example, some prospective mathematics teachers asserted that mathematically gifted students should be assisted in the classroom context; others stated that such students should be supported with out-of-class activities rather than helping them in the classroom. Besides, the participants suggested that the history of mathematics and advanced mathematics subjects could also be used to educate mathematically gifted students.
\end{abstract}

Keywords: Giftedness in mathematics, mathematically gifted students, classroom environment scenarios, secondary school level, prospective teachers.

\section{Introduction}

The people leading all kinds of technological advances in today's world may be considered as gifted individuals, who are probably the most important natural resources of their own countries and even of the world. Researchers studying giftedness are interested in how these individuals' abilities would be developed. In recent years, giftedness is also one of the topics attracting attention in the mathematics education literature (Yazgan-Sag 2019). What kind of education can be given to mathematically gifted students, especially at the secondary level, and what kinds of elements this type of education should include are among the most challenging issues in the literature (Karsenty, 2014).

\footnotetext{
1 gonulyazgan@gazi.edu.tr

${ }^{2}$ This study was presented as an oral presentation at $4^{\text {th }}$ International Symposium of Turkish Computer and Mathematics Education (TURCOMAT), Dokuz Eylül University, 26-28 September 2019, Çeşme, Turkey.
} 
When examining the limited number of giftedness studies in the mathematics education literature (Leikin, 2009, 2011; Singer, Sheffield \& Leikin, 2017), the outstanding ones address the characteristics of mathematically gifted students (Hong \& Aqui, 2004; Krutetskii, 1976). The studies conducted in this field have revealed that mathematically gifted students have intuitive awareness of exploring mathematical proofs and principles (Sriraman, 2004). These students can also be described as individuals who can distinguish mathematical structures, abstract, generalise and reason; think flexibly and backwards about mathematical operations, apply analogical and intuitive thinking, pose alternative problems related to the problems that have been solved, comprehend very complex structures, and work with these structures (Krutetskii, 1976; Miller, 1990; Sriraman, 2003; Van Harpen \& Sriraman, 2013). There are also studies in the literature on learning environments and approaches to meeting their needs in the classroom (Deizmann \& Watters, 2001; Leikin, 2010). These studies emphasise the importance of challenging mathematically gifted students, assigning tasks with appropriate levels of difficulty in their learning environments. It is recommended to prepare positive environments that provide motivation-based learning, which enable gifted students to switch between mathematical concepts and representations of these concepts, participate actively in learning processes, emphasise mathematical discussions and prove processes through their own knowledge, and conduct research by exploring (Davis \& Rimm, 2004). However, these recommendations cannot be realised regardless of the mathematics teachers' knowledge, awareness, and beliefs about the educational programmes they are using and their capacities to include these recommendations to their classrooms (Leikin, 2010).

In the light of the above-mentioned issues, studying the profiles of those who teach mathematically gifted students has become a recent topic of interest. There are only a few studies focusing on the mathematics teachers of mathematically gifted students (Karp, 2010; Karsenty, 2014; Leikin, 2011). Karsenty (2014), who studied on mathematics teachers attending a professional development course on educating gifted students, emphasised that the teachers of mathematically gifted students should have strong mathematics knowledge, strong pedagogical skills, and strong personal social qualities. One remarkable result of her study was that interacting with gifted students improved the teachers' subject matter knowledge and their pedagogical knowledge. Leikin (2011) provided a profile of a Russian mathematics teacher who taught mathematically gifted students for many years and had considerable experience in this field. In this context, the teacher of mathematically gifted students should; (i) have strong mathematical content knowledge, (ii) distinguish among individual differences of each student and challenge them in accordance with these differences, (iii) be supportive and respectful to their students, (iv) be enthusiastic about mathematics, and ( $v$ ) have a good sense of humour to prepare a classroom environment with positive and joyful learning. Therefore, in the light of these studies, the interactions teachers have with mathematically gifted students in the classrooms, and the elements of these interactions are one of the notable topics in mathematics education. Mathematics teachers may foster or hinder students' mathematical giftedness by constructing the classroom atmosphere, choosing teaching approaches, and being aware of their students' levels. Such teacher actions can affect students' interests or disinterests to mathematics in the classroom (Freiman \& Sriraman, 2007).

Mathematically gifted students generally receive their education in heterogeneous classes in the current education system, which is considered a problematic issue in the literature (Applebaum, Freiman \& Leikin, 2011; Shayshon, Gal, Tesler \& Ko, 2014). Teachers' knowledge and beliefs influence approaches and the mathematical content that they use in the 
classrooms. For example, if teachers are not proficient enough, they may not be able to deal with gifted students in their classroom; they may not understand these students' original problem-solving methods and, thus, be unable to support them to think creatively and critically. On the other hand, the mathematics teacher may believe that students who have mathematical potential get good grades on the examinations and behave decently in the classroom. From this point of view, students who produce their own solutions for problems and behave inappropriately because they are bored can be perceived as students who cause problems in the classroom (Applebaum et al., 2011). In this sense, teachers' awareness and education has a key role in terms of creating opportunities for mathematically promising students to realise their own potential (Even, Karsenty \& Friedlander, 2009). Briefly, a mathematics teacher undoubtedly plays an active, and important role in fostering students' mathematical giftedness, encouraging them to use their own potential and expanding their existing interests. From this point of view, as prospective secondary mathematics teachers are about to start their teaching careers in future classrooms, thinking about possible interactions with mathematically gifted students might contribute to their professional development. Furthermore, providing evidence of how prospective secondary mathematics teachers, who are about to complete undergraduate education, get ready to work with mathematically gifted students might contribute to the teaching education literature. In this context, this study's purpose is to reveal prospective secondary mathematics teachers' views about the kinds of behaviours they exhibit in possible interactions with mathematically gifted students in a classroom environment.

\section{Method}

The participants in this qualitative study (Denzin \& Lincoln, 1998) were selected among prospective teachers who were senior students in the secondary mathematics teaching programme of a state university in Turkey in the 2018-2019 academic year. The researcher asked 17 prospective secondary mathematics teachers attending a 'Teaching Methods' course to write their views about giftedness, mathematical giftedness, mathematically gifted students, learning and teaching activities for mathematically gifted students, and mathematics teachers of mathematically gifted students. Then, a focus group interview was conducted with seven of these prospective teachers (Patton, 2002). This focus group interview gave the prospective secondary mathematics teachers an opportunity to express their views in more detail. They also had an opportunity to reflect on other prospective teachers' thoughts actively. Thus, from different perspectives, the issues related to mathematical giftedness were discussed more deeply, and in a rich way. The researcher firstly examined the seven participants' written statements and prepared various questions for the focus group interview. Although these questions were prepared specifically for each participant, the researcher encouraged the other participants to share their views during the interview. The 90-minute focus group interview was recorded with a video camera. During the focus group interview, the participants described mathematically gifted students' characteristics and their past experiences with gifted students. Using these stated characteristics and experiences as reference, the researcher brought up possible mathematics classroom scenarios (vignettes) and asked the participants to think about them. With the help of scenarios, it became possible to select various situations that were the subject of the related study and to trigger the opinions of the individuals participating in the study about these situations (Hughes \& Huby, 2002). This allowed participants to think about how they would behave in narrated situations and, thus, discuss the scenario from their own perspectives in their own words (Barter \& Renold, 2000). In the focus group interview 
conducted in this study, the prospective teachers stated their own views through possible scenarios introduced by the researcher. A researcher-guided discussion, which is thought to be quite productive, was prepared among prospective secondary mathematics teachers. This study took into consideration only the views of the prospective teachers' related behaviours they could display and methods they could present in a possible classroom environment. The classroom scenarios discussed during the focus group discussion are included in the findings section (Table 1 and Table 2). The researcher analysed the raw data with descriptive analysis method in order to organise and interpret the participants' views on these scenarios (Patton, 2002).

\section{Findings}

This section includes the prospective secondary mathematics teachers' views about what they could do in possible interactions which emerged during the focus group interview. Two scenarios related to classroom environments that emerged during the interview and the participants' views about these scenarios are presented to the reader in detail.

Table 1. Scenario 1

Onur: There was a graduate course in the 'Bahar Mathematics Meeting' held at Middle East Technical University. There was a student, he was a normal high school student, and he was attending the course with us. Cayley graph was taught in the course; I could not understand. Even though probably it was the first time he attended the course, he was asking 'why this part is like this?. He then could comment on this subject, I could not do it, for example, although I was a senior student. [... ] For half an hour, the lecturer introduced the Cayley graph. I only knew its name: 'Cayley graph'. It was obtained by connecting like a tree, something like a tree. You were connecting $\mathrm{S}_{3}$ [talking about symmetry group] something like that. That student might never have seen the graphs, but he kept asking 'why it is like that? 1, 2, why o?'. For example, the lecturer did something wrong, 'I think, this part is wrong' he said. Then, the lecturer thought for a while and said 'Yes, it was wrong'. 'Where do you study' asked the lecturer, he said 'at high school'. [... ] Yes, for example, I was bored for that 30 minutes, I did get bored.

Seval: [... ] I do not remember exactly the question he was asking, but he associated things explained there about Cayley graph with another subject [in math] and then asked the question.

Onur: His behaviours were different.

Seval: Yes, his mother and father came too; we saw them during lunch break. I guess he was a gifted one.

Onur: Yes, I thought the same thing; it was obvious from his attitudes, thoughts and movements.

Researcher: 'Forcing to explain' you said, what did you mean? Let us try to understand together.

Seval: Here, I meant asking questions that challenge the lecturer. The girl who was giving the course thought and thought, I think she was taking master's degree, he asked a question, then she could not answer that question, and she said 'Let's communicate through e-mail or something.'

Onur: She was saying 'Yes it is', 'but I couldn't find the answer right now'. 'It is absolutely that, but I couldn't connect them right now.' 
The dialogue given in Table 1 is a part about the conversation between a student and the lecturer who gave the lecture within the scope of the 'Bahar Mathematics Meeting', in which Seval and Onur participated, where they witnessed the course about the graph theory. The researcher took this section as a scenario and let prospective secondary mathematics teachers to examine it during the focus group interview. When considering Onur's and Seval's views about this situation, the researcher addressed the following question of all the participants. Here, the researcher wanted the participants to think about their behaviours in the context of the classroom environment.

Researcher: When teachers face with a situation like the one you two [referring to Onur and Seval] had during the mathematics meeting in their classroom, how should they behave? For example, you have such students in your class. The students are pushing you, but they are also sure about the issue, how can we say, they are a little confident, right? I guess you can imagine the environment described by Seval and Onur. What do we do when we stay with such a situation?

In such a situation mentioned, Ayşe stated that it would be more appropriate to meet with the student after the lesson. She felt engaging in dialogue with a student during class time was an incorrect approach. Ayşe also stated that talking to a gifted student about the question may affect the general progress of the lesson.

Ayşe: I would ask him/her to come after class and talk together. During the lesson, if the student is gifted, I would not want to go into such a conversation and start an ego war no matter how I knew the subject well, so it should be after the course. It may affect my value in the eyes of other children, so I would want to search the answer together in a room or anywhere after the course, so I can learn and let us learn together.

Ayşe was concerned that other students may question her authority in the classroom during such discussion. Along with her concern, Ayşe expressed that she tended to answer the gifted students' questions outside the classroom. Ayşe was willing to help the student with the subject even if she could not answer the question he/she asked. Similarly, Onur also stated that discussing the gifted student's question in the classroom may cause other students to interpret this situation differently:

Onur: If we start to discuss or try to answer that student's question in the class, the other students say 'the teacher is always pay attention to this student'. [...] For example, this happened in my high school [...] Students in the classroom can use the gifted student to disrupt the lesson. 'You ask this question today, say I don't get it, force the teacher, and disrupt the lesson' they say, I mean in our education system.

Onur claimed that considering the question or questions a gifted student asked during the lesson may lead other students to think that the teacher was directing all of his/her attention to that student. He also gave an example from an event he experienced in the class before. He stated that the students who tended to disrupt the lesson could direct the lesson by taking advantage of gifted students' potential to ask questions about classroom topics. Here, prospective secondary mathematics teachers predicted that the questions gifted students asked might disrupt the classroom environment, which would make the classroom 
management difficult. At this point, the researcher tried to revise the possible in class scenario with the following explanation by considering Ayşe's and Onur's thoughts.

Researcher: Here, the fact that the gifted student's smarty attitude in the class can actually be considered as an extreme situation. In fact, that student wants to meet his/her need in the classroom environment at that moment. He/she wants to learn the answer to that question that comes to his/her mind. When we evaluate such classroom environment in this context, what would you like to say?

With this question, the researcher wanted prospective mathematics teachers to focus on the mathematically gifted student figure, rather than the teacher figure, in the scenario. The fact that the participants who spoke in the previous discussion considered the gifted student as a possible threat to an orderly classroom environment caused the researcher to intervene. One of the participants, Gamze, expressed her view as follows:

Gamze: During the lesson, we can give a little information about the question asked by the student, and say, 'Let's talk about this at the break'. I think that some information should be given when the student asks a question in the class.

Here, Gamze stated that she would answer part of the student's question at the time of the lesson and engage in a detailed discussion after the lesson. Other prospective mathematics teachers, Onur, Kumru and Seval, agreed Gamze's behaviour was appropriate. Onur's and Rana's views supported Gamze's recommended behaviour and provided different ideas, which are given below:

Onur: If the teacher does not respond the gifted student at that moment, the other students in the classroom may think 'does the teacher not know?'.

Rana: Others may have a question mark in their minds, for example, depending on the type of question they are asking, there may be such a disruption in the classroom such as asking 'What was it?'. If it is a small thing, I would explain it and by saying 'but if you want to know more, we can talk after the class', you can continue to the lesson.

Onur implied that not answering the question would put the teacher in an awkward position in front of the other students. It might give them the impression that the teacher lacks knowledge of the subject matter. Onur stated his views about the teacher's position from a student's perspective. His perspective on the teacher's authority in the classroom was based on his own experiences as a student. Unlike Onur, Rana expressed her views on the learning of all the students in the classroom. She expressed that the other students could think about the question that the mathematically gifted student asked, which could arouse their curiosity. Rana stated that answering the student's question at that moment would be positive in that it would satisfy the other students' curiosity. From her perspective, she thought she should provide an explanation in the classroom, but talk with the gifted student further after the lesson. The other participants, Ayşe and Nida, also expressed their thoughts about answering the gifted student's questions in the classroom by considering different issues:

Ayşe: I thought as follows: 'what if I do not know the answer of the student's question?' If I do not know at that moment, I can't answer to that student, I mean, I 
also cannot lie. I would say 'Let's not disrupt the lesson, write this down and come to discuss during the lunch break in a spare time'.

Nida: If I were in such a situation, I would give a tiny bit of information about the question, and then I would go into detail after the lesson. That's because if I went into detail there, other students in the classroom would lose their attention to the lesson.

Ayșe: I also agree with Nida, not everyone in the classroom may be interested in the same thing.

Nida: One more thing, if it is more advance than the interest or knowledge of the other students, if we will go above the level of the others, they will not understand anyway, I do not want to make mathematics more difficult in their eyes.

Ayşe brought up a topic that was not emphasised by the other participants: Not knowing the answer to the question that the mathematically gifted student had asked at that moment. Ayşe stated that, in such a situation, it would be more appropriate to discuss the student's question outside the lesson hours instead of thinking about the question in the classroom at that moment. Nida, on the other hand, stated that providing a brief answer and providing more details outside the classroom would be more appropriate. Here, Nida argued that the other students' knowledge and their potential difficulty in maintaining interest in a hard lesson should be also taken into consideration. Therefore, she stated that giving a comprehensive answer to the gifted student's question may disrupt the classroom environment.

Table 2. Scenario 2

Researcher: There is a student, as we just mentioned, in your class that is a student who has the indicators such as quick comprehending, fast calculating, associating, having different perspectives and enjoying while doing mathematics. Therefore, let us say you have one or even two or more mathematically gifted students, when you deal with a subject, they get bored in the lesson and their attentions are distracted, they may already know that subject, and you realise this situation. Functions, for example, how many acquisitions were there in the programme?

Kumru: There were 12 hours, 3 weeks, I think there were 6 acquisitions.

Researcher: You have begun the functions, and you know he/she gets bored in this way, and you have to continue the lesson, what would you do?

In the focus group interview, the prospective secondary mathematics teachers shared their views about a new scenario, given in Table 2. For example, Rana predicted that another activity could be given to the gifted student in the classroom. However, she later stated that the other students in the classroom could react to this situation:

Rana: I thought that a different activity could be given to such a student during the lesson but this time, would we get the reactions of the other students in class? Saying something like 'teacher is paying more attention to him/her, showing different information'.

Here, Rana stated that giving a different activity to a mathematically gifted student might lead the other students to worry about unequal treatment. Upon this situation, the researcher asked the participants, 'Is there anyone who believes that, after all, that student also has 40- 
45 minutes in the classroom: I do not care what other students think, but I would still give different activity?' In response to that question, Kumru's views are given below:

Kumru: To be honest, I couldn't get out of this problem. The students are in one side, and this student is on the other side, yes, that student would have wasted time, [...] I have to give an activity to that student, it might be related to math, or I might have given a problem before, a challenging problem. He/she is different, since I realised that the student is a special one, I believe that it would be better for that student to say 'you keep thinking on this question' or 'you check out these questions' in the activities I gave. He/she would discomfort the other students by making a lot of noise and disrupting the order of the class, so he/she would be a different student in the eyes of the other students anyway, I believe that the best winning method is the one said by Rana.

Kumru stated that different activities, independent from the subject mentioned at that time, can be given to include the gifted student in the classroom. In addition, Kumru found it appropriate to share different activities with that student based on the belief that this student, who gets bored, could disrupt classroom order. Rana began to speak and emphasised her earlier thoughts by stating that 'I would prefer to get a reaction because I wouldn't lose that student'. Later, Ayşe and Kumru came up with the idea of sharing different books which did not have to be related to the subject mentioned in the classroom, with the mathematically gifted students. However, Ayșe added that such sharing should be done when the other students were absent, so they would not feel inadequate by comparing themselves with the gifted student.

Ayşe: $[. .$.$] a book can be given to that student, in a place where there are no other$ students around. It can be said that 'You can deal with this while waiting your friend when he/she gets bored in classroom or when he/she solves a problem'. It can be an advance book about that subject.

Kumru: There are books of the Teacher Ali [referring to Ali Nesin] for science high schools, for example, they are advance books teaching mathematics at a higher level, perhaps at the level we take in the university. Showing these types of books specific for those children and making them to think about those subjects are important in my opinion. I think, those children will be satisfied with them. A little more advance mathematics is full of subjects that will challenge them. As a book, I recommend that book. That's because, since we know with such books as we saw in our undergraduate education, we can easily help, it would be about mathematics, I believe we can win that student more easily in this way.

When the participants' explanations were taken into consideration, it was seen that they had the idea that various books with mathematics contents that are more advanced compared to the classroom levels or in undergraduate level can be shared with mathematically gifted students. Kumru stated that these types of books would create a challenging situation for gifted students, and these students can be satisfied in the classroom with this way. On the other hand, Onur added that the gifted student can deal with other subjects, with the teacher's guidance, independent of the specific content (e.g. function) after getting advanced lesson content by saying that 'the student may study the other math subjects after conducting the advanced reading in functions.' Similarly, Gamze also stated that different mathematics problems can be shared with the gifted students at the time of the lesson: 
Gamze: I think it is important to raise the awareness about mathematics, that is, not only the function subject, I don't know maybe math problems or something can be examined. At that moment, for example, a more updated subject might be brought up that may draw the attention of the other students in which I may added that student over time. For example, by saying 'Fermat's theorem has not been solved for 200 years', this will satisfy that student, it can be done to continue the lesson.

Here, Gamze emphasised that different investigations can be made with these students, not only for helping the gifted student learn about any subject in mathematics (e.g. function), but also for raising awareness about mathematics in general. She also stated that, for this purpose, mathematics problems that could not be solved until today, or a current mathematics case can be shared with students. She also suggested that engaging in such interactions with mathematically gifted students during the lesson may also attract the attention of the other students in the classroom. Rana also supported Gamze's such idea by saying that 'I think we can use the history of mathematics; it definitely attracts that student's attention'.

\section{Discussion, Conclusion, and Recommendations}

This study aimed to reveal the views that prospective secondary mathematics teachers have about their possible interactions with mathematically gifted students in a classroom environment. Data from two possible scenarios, which emerged during focus group interviews with seven prospective secondary mathematics teachers about mathematically gifted students and their teachers were discussed within the scope of this study. The study results indicated that the prospective secondary mathematics teachers had different approaches to the cases they may encounter in classroom. One was the tendency to help mathematically gifted students mostly outside the classroom. They claimed that trying to answer the gifted student's question about the mathematical content discussed in the classroom, or being in a (mutual) dialogue with these students about the questions could disrupt the planned lesson and classroom order. This may be due to the participants' negative experiences with their teachers' classroom behaviour during their past experiences as students (Applebaum et al., 2011). On the other hand, not knowing the answer to the mathematically gifted student's question at that moment was another reason for helping that student outside the classroom.

The prospective secondary mathematics teachers also thought they should address the issues raised in the context of the classroom briefly, at that moment, but also to support such students later with out-of-class activities. They were concerned with other students questioning the teacher's knowledge and authority if the mathematically gifted student's question was not answered at that moment. On the other hand, the participants also thought that the mathematically gifted student's question could stimulate all students' thinking rather than affecting the classroom teacher's position. Finally, the participants stated that giving very detailed explanations to a gifted student at the moment may be much more challenging for the other students who would have difficulty in maintaining interest in mathematics lessons.

The study participants also suggested activities supporting mathematically gifted students in the classroom environment. Many of the prospective teachers stated that it may be appropriate to assign different activities to gifted students, who can get bored with the 
mathematical content being discussed in the classroom. They also believed that the activities for the mathematically gifted students could be not only related to the current mathematical content at that moment but also related to different mathematical topics. They even stated that mathematical books containing undergraduate course content could be shared with gifted students in the classroom. However, they also pointed out that giving these types of activities only to mathematically gifted students may cause other students concern over unequal treatment. The dilemma of teachers treating all students equally in the classroom is also among the main issues in giftedness literature (Shayshon et al., 2014). In addition, prospective secondary mathematics teachers also suggested that the history of mathematics and current advanced mathematics topics could be used to educate mathematically gifted students. The participants stated that this approach may increase the mathematically gifted student's awareness of situations where they may encounter mathematics.

Consequently, the participants could not provide very detailed explanations about how they could interact with gifted students in the classroom. Their explanations were mostly based on their own experiences as students. This may be due to the fact that they did not have enough knowledge and experience about (mathematical) giftedness during their undergraduate education. Similar to the literature, the importance of giving more space to such course content will increase prospective teachers' knowledge and awareness of above-average students in undergraduate mathematics teaching programmes, which has also emerged in this study (Karsenty, 2014). On the other hand, benefiting from the experiences of the teachers of gifted students and interacting with these students may improve the skills of prospective secondary mathematics teachers in this direction (Karp, 2010; Karsenty, 2014). For this reason, prospective teachers should be in environments where they can interact with mathematically gifted students, not only in the context of theoretical courses but also in the context of courses that increase their practical experiences, such as school experience and teaching practice.

\section{References}

Applebaum, M., Freiman, V., \& Leikin, R. (2011). Prospective conceptions about teaching mathematically talented students: Comparative examples from Canada and Israel. The Montana Mathematics Enthusiast, 8(1-2), 255-290.

Barter, C., \& Renold, E. (2000). I wanna tell you a story: Exploring the application of vignettes in qualitative research with children and young people, International Journal of Social Research Methodology, 3(4), 307-23.

Davis, G. A., \& Rimm, S. B. (2004). Education of the gifted and talented. Boston, MA: Pearson Education Press.

Deizmann, C. M., \& Watters, J. (2001). The collaboration of mathematically gifted students on challenging tasks. Journal for the Education of the Gifted, 25, 7-31.

Denzin, N. K., \& Lincoln, Y. S. (1998). The landscape of qualitative research: Theories and issues. Thousand Oaks, CA: Sage Publications.

Even, R., Karsenty, R., \& Friedlander, A. (2009). Mathematical creativity and giftedness in teacher professional development In R. Leikin, A. Berman \& B. Koichu (eds.), Creativity in Mathematics and the Education of Gifted Students (pp. 309-324). Rotterdam, The Netherlands: Sense Publishers. 
Freiman, V., \& Sriraman, B. (2007). Does mathematics gifted education need a working philosophy of creativity? Mediterranean Journal for Research in Mathematics Education, 6(1-2), 23-46.

Hong, E., \& Aqui, Y. (2004). Cognitive and motivational characteristics of adolescents gifted in mathematics: Comparison among students with different types of giftedness. Gifted Child Quarterly, 48, 191-201.

Hughes, R., \& Huby, M. (2002). The application of vignettes in social and nursing research. Journal of Advanced Nursing, 37(4), 382-386.

Karp, A. (2010). Teachers of the mathematically gifted tell about themselves and their profession. Roeper Review, 32(4), 272-280.

Karsenty, R. (2014). Who can teach the mathematically gifted? Characterizing and preparing mathematics teachers of highly able students at the secondary level. Gifted and Talented International, 29(1-2), 161-174.

Krutetskii, V. A. (1976). The psychology of mathematical abilities in schoolchildren. Chicago: University of Chicago Press.

Leikin, R. (2009). Bridging research and theory in mathematics education with research and theory in creativity and giftedness. In R. Leikin, A. Berman \& B. Koichu (eds), Creativity in mathematics and the education of gifted students (pp. 383-409). Rotterdam: Sense Publishers.

Leikin, R. (2010). Teaching the mathematically gifted. Gifted Education International, 27(2), 161175.

Leikin, R. (2011). Teaching the mathematically gifted: Featuring a teacher. Canadian Journal of Science, Mathematics and Technology Education, 11(1), 78-89.

Miller, R. C. (1990). Discovering mathematical talent, Reston, VA: Eric Clearing House on Handicapped and Gifted Children. (ERIC Document reproduction Service No. ED321487)

Patton, M. Q. (2002). Qualitative research and evaluation methods. Newbury Park: Sage Publication.

Singer, F. M., Sheffield, L. J., \& Leikin, R. (2017). Advancements in research on creativity and giftedness in mathematics education: Introduction to the special issue. ZDM Mathematics Education, 49(1), 5-12.

Shayshon, B., Gal, H., Tesler, B., \& Ko, E.-S. (2014). Teaching mathematically talented students: A cross-cultural study about their teachers' views. Educational Studies in Mathematics, 87(3), 409-438.

Sriraman, B. (2003). Mathematical giftedness, problem solving, and the ability to formulate generalizations. Journal of Secondary Gifted Education, 14, 151-165.

Sriraman, B. (2004). Gifted ninth graders' notions of proof. Investigating parallels in approaches of mathematically gifted students and professional mathematicians. Journal for the Education of the Gifted, 27, 267-292.

Van Harpen, X. Y., \& Sriraman, B. (2013). Creativity and mathematical problem posing: an analysis of high school students' mathematical problem posing in China and the USA. Educational Studies in Mathematics, 82(2), 201-222.

Yazgan-Sag, G. (2019). A theoretical view to mathematical giftedness. Milli Egitim Dergisi, 48(221), 159-174. 


\section{Biographical notes:}

Dr. Gönül YAZGAN-SAĞ is a Research Assistant in the Department of Mathematics and Science Education, Division of Mathematics Education, at Gazi University, Turkey. Her current research interests are mathematically gifted students, problem solving, mathematical creativity, teacher education, and self-regulated learning. 